\title{
The Th1:Th2 Dichotomy of Pregnancy and Preterm Labour
}

\author{
Lynne Sykes, ${ }^{1}$ David A. MacIntyre, ${ }^{1}$ Xiao J. Yap, ${ }^{1}$ Tiong Ghee Teoh, ${ }^{2}$ and Phillip R. Bennett ${ }^{1}$ \\ ${ }^{1}$ Parturition Research Group, Department of Surgery and Cancer, Institute of Reproduction and Developmental Biology, \\ Imperial College London, London W12 ONN, UK \\ ${ }^{2}$ St Mary's Hospital, Imperial College Healthcare NHS Trust, London W1 2NY, UK \\ Correspondence should be addressed to Lynne Sykes, 1.sykes@imperial.ac.uk \\ Received 9 February 2012; Accepted 18 April 2012 \\ Academic Editor: Noboru Uchide \\ Copyright () 2012 Lynne Sykes et al. This is an open access article distributed under the Creative Commons Attribution License, \\ which permits unrestricted use, distribution, and reproduction in any medium, provided the original work is properly cited.
}

Pregnancy is a unique immunological state in which a balance of immune tolerance and suppression is needed to protect the fetus without compromising the mother. It has long been established that a bias from the Thelper 1 cytokine profile towards the T helper 2 profile contributes towards successful pregnancy maintenance. The majority of publications that report on aberrant Th1:Th2 balance focus on early pregnancy loss and preeclampsia. Over the last few decades, there has been an increased awareness of the role of infection and inflammation in preterm labour, and the search for new biomarkers to predict preterm labour continues. In this paper, we explore the evidence for an aberrant Th1:Th2 profile associated with preterm labour. We also consider the potential for its use in screening women at high risk of preterm labour and for prophylactic therapeutic measures for the prevention of preterm labour and associated neonatal adverse outcomes.

\section{Introduction}

Preterm labour occurs in some $10 \%$ of pregnancies [1]. In many developed countries, the rates are rising. Birth before 37 weeks of gestation is thought to account for up to $70 \%$ of neonatal deaths, and the extremely high neonatal intensive care costs required to support those who do survive make preterm birth both a social and economic burden. It is now widely acknowledged that the aetiology of preterm labour is multifactorial, and, as such, the underlying cause of preterm labour is often unknown. There is a strong association between preterm labour and infection and inflammation, and research in this field has dramatically increased over the last few decades [2]. However, we still have made little significant progress in the prevention of preterm labour. Evidence of the detrimental direct impact of maternal infection/inflammation on neonatal outcome is emerging, yet we do not fully understand if anti-inflammatory therapeutic agents would provide benefit or harm to the neonate born under conditions of infection/inflammation-induced preterm labour.

The immunology of pregnancy is complex, in that the mother must tolerate the "foreign" fetus, and thus requires a degree of immunosuppression whilst on the other hand needs to maintain immune function to fight off infection. One mechanism which is involved in successful pregnancy maintenance is the proposed switch from the T helper 1 (Th1) cytokine profile to the T helper 2 (Th2) profile. This paper explores the evidence for an imbalance in the Th1:Th2 profile in women at risk of and who are in established preterm labour.

\section{The Immunology of Pregnancy}

The fetus can be described as a semiallogeneic graft, being a product of two histoincompatible individuals $[3,4]$. This poses a challenge to the mother, to both tolerate and accommodate the fetus, which will express paternal antigens, and maintain an ability to reject in case of overwhelming infection [5]. This challenge is undertaken in part by the immune system. The immune system has two main defence systems: the innate and the adaptive. The innate immune response is a nonspecific reaction towards foreign antigens, whereas the adaptive response forms a very specific reaction towards antigens [6]. Although different immune components are involved in these systems, much overlap and 


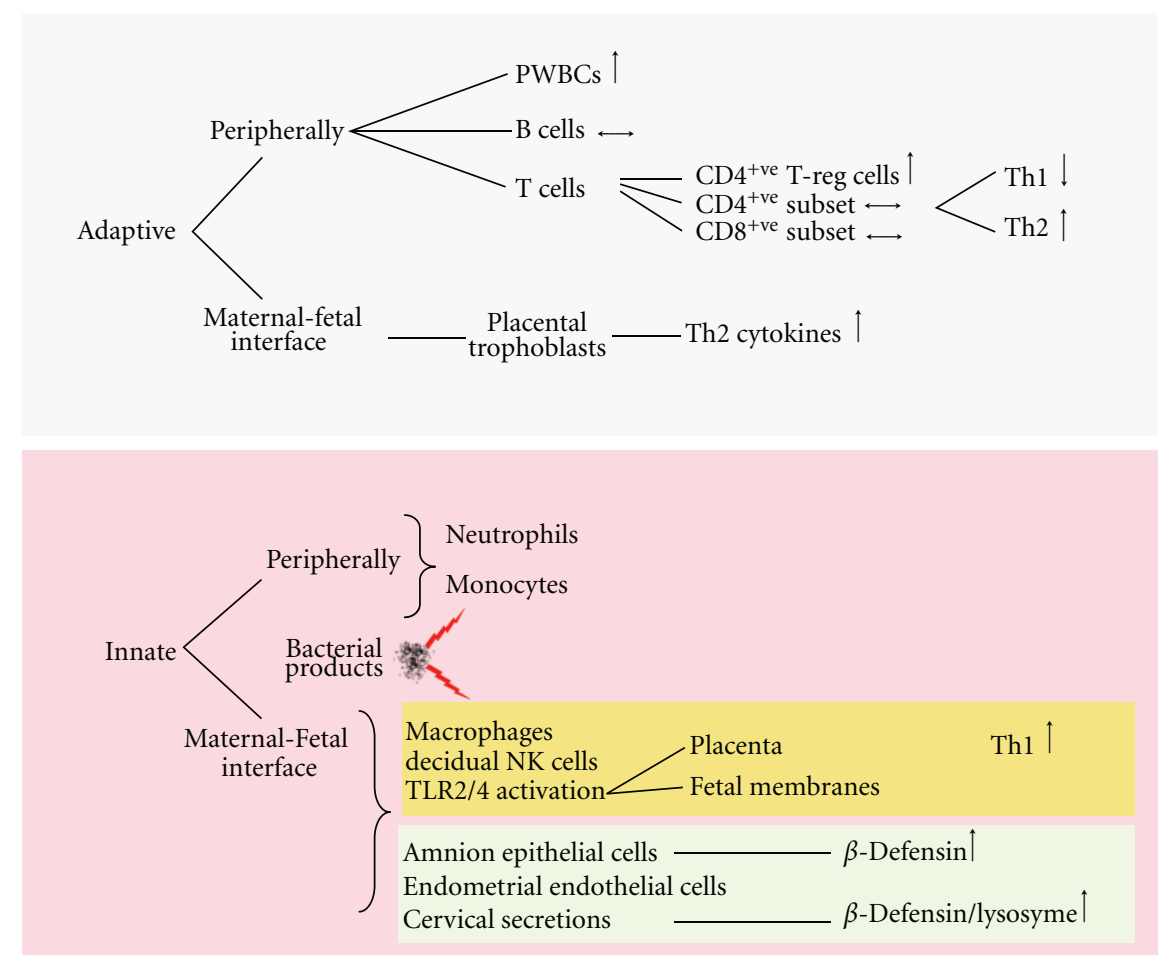

FIGURE 1: Summary of the adaptive and innate immune system in pregnancy. Mediators of the adaptive and innate immune system work in parallel to facilitate a balance between immune tolerance of the fetus whilst maintaining the ability to mount a response against invading pathogens. PWBC: peripheral white blood cells.

cross-talk exist between the two. Figure 1 summarises the key elements of these systems during pregnancy.

The immune cells that make up the adaptive immune response include $\mathrm{B}$ and $\mathrm{T}$ lymphocytes. Activation by antigen presenting cells and cytokines leads to cytokine release by $\mathrm{T}$ cells in a cell-mediated response, or antibody release by B cells in a humoral response [7]. Although Medawar originally hypothesised that pregnancy represents a time of immune suppression [8], a more complex picture has recently emerged where a change in the ratio and functionrather than a complete suppression-of the maternal leukocytes occurs during pregnancy. For example, there is an increase in the total peripheral white cell count from the early stages of pregnancy with no change in the CD4 and CD8 counts [9]. Within the CD4 positive population, an increase in T regulatory cells is seen in pregnancy [10]. The function of the $\mathrm{T}$ cells adapts in pregnancy to favour the $\mathrm{T}$ helper 2 cytokine profile, which is more pronounced at the maternal fetal interface [11]. Nonimmune cells, for example, placental trophoblasts also contribute to the Th2 cytokine predominance in pregnancy [12].

The innate immune system provides a less specific response nevertheless is critical for the prevention of microbial invasion. Cellular components include neutrophils, monocytes, and macrophages, which protect against pathogens by phagocytosis. The Toll-like receptors (TLRs) TLR2 and TLR4 are pattern recognition receptors stimulated by Gram-positive and Gram-negative bacteria, respectively [1]. TLRs are expressed on nonimmune cells in the placenta and fetal membranes, which mediate part of the innate immune system at the maternal fetal interface [13]. TLR2 and 4 mutations are associated with an increased risk of preterm birth $[14,15]$. During pregnancy, there is tight regulation and considerable cross-talk between the adaptive and the innate adaptive immune system that is responsible for preventing or activating rejection of the conceptus.

\section{Th1:Th2 Cytokines}

T helper 1 and 2 cell subsets originate from undifferentiated Th0 cells under the influence of interferon-gamma (IFN- $\gamma$ ) and interleukin-4 (IL-4), respectively. Pregnancy hormones such as progesterone [16], leukaemic inhibitory factor [17], estradiol [18], and prostaglandin $\mathrm{D}_{2}\left(\mathrm{PGD}_{2}\right)$ [19] promote the $\mathrm{T}$ helper 2 cell profile and are likely to be in part responsible for the Th2 bias associated with pregnancy.

Type $1 \mathrm{CD}^{+} \mathrm{T}$ cells (Th1) produce an array of inflammatory cytokines including IFN- $\gamma$ [20], IL-2 [21], and Tumor necrosis factor-alpha (TNF- $\alpha$ ) [22] and are the major effectors of phagocyte-mediated host defence, protective against intracellular pathogens $[21,23,24]$. Type $2 \mathrm{CD}^{+}$ T cells (Th2) produce IL-4, IL-5, IL-13, IL-10 [20], and IL-6. Whilst IL-4 and IL-10 are considered to be antiinflammatory cytokines [25], IL-6 has proinflammatory properties [26]. Although IL-10 and IL-6 are frequently referred to as Th2 cytokines [27-32], they are both produced by other cell types including Th1 cells, macrophages, and B cells for IL-10 [33, 34], and macrophages, fibroblasts, and B 
cells for IL-6 [35]. The T helper 2 cytokines are commonly associated with strong antibody responses [36], for example, IL-4 stimulates $\operatorname{IgE}$ and $\mathrm{IgG}_{1}$ antibody production [37]. However, the Th2 cytokines also serve other functions, for example; IL-5 promotes the growth and differentiation of eosinophils, whereas IL-13 and IL-10 inhibit the activity of macrophages [37]. T helper 2 cell responses are also associated with protection against parasites, since IL-4 mediates IgE production, and IL-5 mediates an eosinophilia, both of which are hallmarks of parasitic infection [38]. It is important to note that, although the Th1 and Th2 responses can be seen as discrete responses, there is considerable crosstalk and overlap between the functions of the T helper cells. For example, the Th1 cytokines can promote the production of complement-fixing antibodies involved in antibodydependent cell cytotoxicity [39], and thus the dichotomy described may be an oversimplified representation of the complex immune system. Transcriptional regulation of the predominant Th2 cytokine IL- 4 is by STAT- 6 , c-maf, GATA3 , and NFAT [40], whereas Th1 cell cytokine production is transcriptionally regulated by T-bet and STAT-4 [11].

\section{Th1:Th2 and Pregnancy Maintenance}

The hypothesis of Th2 predominance and downregulation of the Th1 response originated from Wegmann and colleagues [41] and was reinforced by evidence from both murine studies and the clinical course of Th2 and Th1 based conditions in pregnancy. IL-2, IFN- $\gamma$, and TNF- $\alpha$ induce miscarriage in mice, which can be reversed by inhibitors of the Th1 cytokines or by administering the anti-inflammatory Th2 cytokine IL-10 [42, 43]. Autoimmune conditions where Th1 is involved in the pathophysiology generally improve in pregnancy (e.g., rheumatoid arthritis [44]), whereas the Th2 autoimmune spectrum tends to worsen (e.g., systemic lupus erythematosus [45]). With a Th2:Th1 bias, the diminished cell-mediated immunity may be responsible for the increased susceptibility in pregnancy of conditions caused by intracellular pathogenesis (e.g., influenza, leprosy, and Listeria monocytogenes [46]).

4.1. Peripheral Blood. Several techniques are available to establish the function of Th1 and Th2 cells in pregnancy; enzyme-linked immunosorbent assay (ELISA) can be used to measure maternal serum interleukins; peripheral $\mathrm{T}$ cells can be isolated and stimulated with a mitogen such as phorbol myristate acetate (PMA) or phytohaemagglutinin (PHA) to measure the cytokine production either by ELISA or flow cytometry during pregnancy compared with nonpregnant controls.

Marzi and colleagues isolated PBMCs, stimulated them with PHA, and measured interleukin secretion by ELISA showing a reduction in IFN- $\gamma$ and IL- 2 and an increase in IL-4 and IL-10 in pregnancy compared with nonpregnant controls [47]. In support of this study, Reinhard et al. stimulated cells with PMA and demonstrated by flow cytometry a reduction in intracellular IFN- $\gamma$ and IL-2, and an increase in intracellular IL-4 production in pregnancy compared with nonpregnant controls [48]. In vivo confirmation of this bias has since been demonstrated by polymerase chain reaction (PCR) reflecting decreasing messenger ribonucleic acid (mRNA) of IFN- $\gamma$ through pregnancy and a concurrent increase in IL-4 mRNA which peaks in the 7th month compared with nonpregnant controls [49]. However, not all studies support the Th1 to Th2 bias. Shimaoka et al. reported a reduction in PMA-stimulated IL-4 during pregnancy [50], while Matthiesen and colleagues presented data suggesting an increase in both IL-4 and IFN- $\gamma$ secreting cells in pregnancy compared with nonpregnant controls $[51,52]$. Such discrepancies may be due to characterisation of cytokine profiles in either isolated cell populations or whole blood, the latter arguably being a more biologically relevant system.

4.2. Maternal Fetal Interface and Nonimmune Cells. While much research has been dedicated toward circulating cytokines in pregnancy, local cytokine production at the maternal interface may be of greater significance than measurements obtained in the peripheral blood [23]. IL4, IL-10, and macrophage colony-stimulating factor (mCSF) production by $\mathrm{T}$ cells at the maternal fetal interface is associated with successful pregnancy [23]. Trophoblast, decidua, and amnion all contribute to the Th2 cytokine environment by production of IL-13 [53], IL-10 [54], IL4 and IL-6 $[55,56]$. Coculture of trophoblasts and T cells results in an increase in the transcription factors GATA3 and STAT- 6 (which regulate Th2 cytokine production), and a reduction in the Th1 transcription factor STAT- 4 and subsequently decreased production of IFN- $\gamma$ and TNF- $\alpha$ [57]. The placenta also synthesises $\mathrm{PGD}_{2}$, which may act as a chemoattractant of Th2 cells to the maternal fetal interface via the classic Th2 receptor CRTH2 (chemoattractant receptor-homologous molecule expressed on Th2 cells) [28]. $\mathrm{CRTH}_{2}{ }^{+}$cells are reduced at the maternal fetal interface of women suffering from recurrent loss compared with women undergoing elective termination [58].

Local production of IL-4 and IL-10 inhibits the function of both Th1 cells and macrophages, which serves to prevent fetal allograft rejection [59]. Other anti-inflammatory effects of these interleukins result in inhibition of the Th1 cytokine TNF- $\alpha[60]$, and TNF- $\alpha$-induced cyclo-oxygenase-2 (COX2 ), and/or $\mathrm{PGE}_{2}$ synthesis in amnion-derived wish cells. Similar effects are observed in decidual and placental cells in vitro [61-64], which is thought to inhibit the onset of labour. Consistent with such a role, decidual CD4 positive cells from women undergoing unexplained recurrent pregnancy loss typically exhibit reduced IL-4 and IL-10 production [65].

\section{Th1:Th2 Cytokines in Labour}

5.1. Peripheral Blood. The Th2 cytokine predominance which exists during pregnancy has been shown to return to nonpregnant Th1:Th2 ratios by 4 weeks postpartum [66]. Labour is often seen as a proinflammatory state marking the end of the pregnancy, and thus it is plausible that labour is associated with a reversal in the bias back towards Th1 rather than Th2. Rather, Kuwajima and colleagues 
have shown that the Th2:Th1 ratio remained constant in favour of Th2 through pregnancy and labour, with a reversal back to nonpregnant parameters at 7 days postpartum [67]. However, this finding is somewhat contrary to an earlier report indicating that serum IL-4 levels measured by ELISA in women through pregnancy and at different stages of labour were reduced in the later part of labour and by day 1 postpartum in both normotensive and preeclamptic women [68]. In this study, the Th1 proinflammatory cytokine TNF$\alpha$ peaked in early labour consistent with labour being a proinflammatory state. Consistent with this, an increase in IFN- $\gamma$ and IL- $1 \beta$ in women in active labour has also been reported [69].

5.2. Maternal Fetal Interface and Nonimmune Cells. There is substantial evidence that the Th1 cytokines play a role in the initiation of labour at term [22]. The importance of local rather than peripheral production of the cytokines is highlighted by their direct input into the biochemical pathways involved in parturition. Fetal membranes $[70,71]$ and myometrium [72] produce IL- $1 \beta$ at term, a potent inducer of NF- $\kappa \mathrm{B}$ [73]. This transcription factor regulates the expression of numerous labour-associated genes including COX-2, the oxytocin receptor, IL-8, and matrix metalloproteinase9 (MMP-9) [74]. TNF- $\alpha$ and IL- $\beta$ are both increased in amnion, amniotic fluid, and decidua at term [75] and can induce $\mathrm{PGE}_{2}$ production in amniocytes and decidual cells in vitro $[76,77]$. Despite the proinflammatory nature of the Th1 cytokines they are required for successful pregnancy contributing to the physiology of term labour.

\section{Th1:Th2 Cytokines in Infection}

Activation of the Th1 cytokines occurs as a specific response to infection caused by intracellular bacteria, parasites, and viruses [78]. The necessary proinflammatory type 1 response elicited by infection, along with the action of the activated $\mathrm{T}$ cells, drives local and systemic cytokine production that, if left unchecked, can be harmful to the host [78]. In some situations, the Th1 response is balanced by the production of Th2 cytokines, particularly IL-4 and IL-10 [79-82]. In the early stages of infection, IL-12 is produced by macrophages and dendritic cells $[83,84]$, which lead to polarisation from Th0 to Th1 type cells [24]. IFN- $\gamma$ enhances Th1 development by upregulating the IL-12 receptor and inhibiting the growth of Th2 cells [85]. IFN- $\gamma$ also primes macrophages to begin phagocytosis and to stimulate the release of interleukin-1 [86].

While the Th1 cytokine response may be suppressed by both the maternal and fetal immune system during pregnancy [87], it still maintains the capacity to mount a defensive response in the context of infection. For example, cord blood mononuclear cells cultured with lipopolysaccharide (LPS) in vitro show an increased production of IFN$\gamma$ concurrent with reduced IL-4 secretion [88]. Similarly, neonates exposed to intrauterine infection have an increased percentage of IFN- $\gamma$-producing cells, with some neonates also showing an increase in IL-4-producing cells [89].
In response to LPS amnion, chorion, deciduas, and placenta also release proinflammatory cytokines $[64,90,91]$.

\section{Th1:Th2 Cytokines in Preterm Labour}

Approximately, $30 \%$ of preterm births are associated with infection [92], with a higher rate of $80-85 \%$ in early preterm birth (<28 weeks) [93]. Immune and nonimmune cells contribute to a cytokine-rich environment in the presence of infection and inflammation. Proinflammatory cytokines such as TNF- $\alpha$ and IL- $1 \beta$ ultimately result in the production of prostaglandins and MMPs [86], via NF- $\kappa \mathrm{B}$. This triggers a cascade of prolabour events including uterine contractility and fetal membrane rupture, and if this cascade is activated early in pregnancy, preterm labour can ensue.

7.1. Peripheral Blood. As discussed above, the peripheral response may not be as potent as the local Th1:Th2 response and may instead reflect a more significant inflammatory response at the fetal placental compartment. A large case control study of 101,042 Danish women showed that an elevated mid pregnancy IFN- $\gamma$ plasma level was associated with moderate and late spontaneous preterm delivery, whereas no increased risk was seen with elevated TNF- $\alpha$ or IL-2 [94]. However, a study comparing women in active preterm labour and no labour looked at mitogen-stimulated production of IFN- $\gamma$ and the Th2 cytokines IL-4, IL-10, and IL-13 and showed no difference in median cytokine production in the supernatant in vitro [86]. The differing results between these studies could be explained by the fact that the in vitro cells lack the presence of other cells of the immune system and thus lack the ability to reflect the complexity of the immune system as a whole. This same study did however show a higher IL-12 and lower IL-4 in cervical secretions of women in preterm labour, reflecting the localised Th1:Th2 dichotomy. Bahar and colleagues did not demonstrate any difference in serum TNF- $\alpha$ or IFN- $\gamma$ in women with preterm labour compared to term labour or matched controls not in labour [95]. However, those women in the preterm labour group received indomethacin, an anti-inflammatory COX-2 inhibitor, which could have dampened a typical proinflammatory response. Serum taken from women with preterm prelabour rupture of membranes (pPROM) compared to women who delivered at term exhibit a higher concentration of IFN- $\gamma$. Levels of IL- 4 and IL-5 were undetectable in both groups [96]. In a study of 30 women in preterm labour, mitogen- and antigenstimulated PBMCs showed a higher production of the proinflammatory cytokines IFN- $\gamma$ and IL-2, along with an altered Th1:Th2 ratio favouring a Th1 response compared with controls who delivered at term [97]. Taken together, these results suggest that, rather than a decrease in the Th2 response, preterm labour most likely represents an activation of the Th1 response. Thus, future development of therapeutic targets would likely be more effective if directed towards the modulation of the Th1 cytokines.

The Th1:Th2 dichotomy likely represents an oversimplification of the complexity of the cross-talk between the 
Th1 and Th2 cytokines. The ratio of Th1:Th2 is likely to be of more physiological importance than the actual concentrations produced. In support of such a notion, women in threatened preterm labour with high serum levels of IL-12 (which induces a Th1 cytokine response) and no change in serum IL-18 (which can induce both Th1 and Th2 response) do not show significant associations with preterm labour. However, women with high IL-12 levels and low IL18 and thus a high IL-12:IL-18 ratio increasing the Th1 predominance are associated with a twofold risk of preterm labour when presenting with threatened preterm labour [98].

7.2. Maternal Fetal Interface and Nonimmune Cells. The inflammatory response at the maternal fetal interface more likely reflects the true importance of the Th1:Th2 dichotomy and the aberrant profile in preterm labour. A recent metaanalysis concluded that proinflammatory cytokines at the maternal fetal interface play a role in the events leading to spontaneous preterm labour, while systemic inflammation does not appear to be present in asymptomatic women early on in pregnancy who then go on to deliver preterm [99]. This is consistent with a more local intrauterine inflammatory response syndrome, where no organisms are identified. Understanding the pathophysiology at the maternal interface is essential for developing new therapies for the prevention of inflammation-induced preterm labour, although using such local changes for the prediction is challenging because of lack of access to the maternal fetal interface.

Placentas from women with pPROM and preterm delivery have higher Th1, inducing cytokines [100], and placentas from women following preterm delivery compared with term delivery show a bias towards the Th1 profile with significantly higher levels of IFN- $\gamma$ and IL-2 as well as the Th1-inducing cytokine IL-12 [100]. Moreover, term placentas exhibit comparatively higher levels of the Th2 cytokines, IL-4, and IL-10, compared with the preterm placentas.

TNF- $\alpha$ is increased in choriodecidual tissues [71] and amniotic fluid [101] in preterm labour. TNF- $\alpha$ is known to stimulate PG production through the TNF receptor 2, leading to uterine contractions likely via activation of NF$\kappa \mathrm{B}$, but is also likely to contribute to MMP-9 production leading to PROM via activation of its receptor TNF Receptor 1 (TNFR1) [102]. Interestingly, samples of myometrium collected women in preterm labour and samples collected preterm before labour express comparable mRNA levels of TNF- $\alpha$. However, mRNA levels of the receptors, TNF R1 A and $\mathrm{B}$, are increased in preterm labour and term labour compared with nonlabour controls [103] suggesting a receptormediated increase in sensitivity to TNF- $\alpha$.

Although placental, amnion, and choriodecidual cells secrete proinflammatory cytokines, cytokine levels in tissues from preterm deliveries (with and without intrauterine infection) correlate with the extent of leukocyte infiltration in fetal membranes [75]. In the presence of infection, the primary cellular source of cytokine production in fetal membranes is likely to be infiltrating leukocytes rather than amniocytes or choriodecidual cells. [75].
7.3. Polymorphisms of the Th1 and Th2 Cytokines. Studying genetic polymorphisms of the Th1 and Th2 cytokines could provide a novel screening method for determining women at high risk of preterm labour. Polymorphisms giving rise to functional alterations can also provide information on the importance of the interleukins in preterm labour. There has yet to be any promising genetic polymorphisms identified in the Th1:Th2 cytokines for the prediction of preterm labour, the work conducted warrants consideration (see Table 1).

\section{Non-Th1:Th2 Interleukins}

8.1. IL-8. Interleukin 8 is a chemokine produced by many immune cells but primarily macrophages and monocytes [116]. Its production is stimulated by LPS, TNF, and IL-1 [117] and, in the context of pregnancy, is thought to attract leukocytes to the gestational tissues and the cervix at the onset of term and preterm labour. IL-8 mRNA expression has been reported to be increased more than 50 -fold in preterm labour and more than 1000-fold in preterm labour with evidence of chorioamnionitis in amnion and choriodecidua [118]. A number of studies have also identified increases of IL- 8 in the myometrium and cervix with the onset of labour $[119,120]$. Placental IL-8 is also higher in preterm deliveries compared with term deliveries [71].

8.2. IL-6. Although IL-6 is produced by Th2 cells, it is a proinflammatory cytokine and a major mediator of host response to inflammation and infection [121]. IL-6 levels are moderately increased in placenta, significantly increased in amnion and choriodecidua in women with preterm delivery compared with term delivery [71]. IL-6 appears to be among the most sensitive and specific indicators of infection-associated preterm labour $[122,123]$. The presence of an increase in IL-6 in amniotic fluid and cervicovaginal fluid is an independent risk factor for preterm labour and neonatal morbidity [124] including cerebral palsy [125] and bronchopulmonary dysplasia [126].

\section{Therapeutic Modulation of Th1 and Th2 Profile}

Various therapeutic strategies have been proposed to prevent preterm labour, with the primary objectives of (1) delaying delivery to increase gestation at delivery and (2) to improve neonatal condition at birth [127]. Currently, many of the strategies adopted for the prevention of preterm labour involve targeting the proposed pathways and events that result in uterine contractions and cervical shortening and dilation rather than targeting immune activation. As described here, an aberrant proinflammatory profile exists in both term and preterm labour, which is associated with neonatal morbidity. The limitation of tocolytics is the inability to counteract the exposure of the fetus to proinflammatory cytokines, which lead to the fetal inflammatory response syndrome. This may in fact worsen neonatal outcome by prolonging the exposure of the fetus to a hostile 
TABLE 1: Cytokine polymorphism associations with preterm labour (PTL).

\begin{tabular}{|c|c|c|c|c|}
\hline Gene & Polymorphism & Th1/Th2 & Function & Reference \\
\hline IFN- $\gamma$ & $+874 \mathrm{~A}>\mathrm{T}$ & Th1 & $\begin{array}{l}\text { Classic Th1 cytokine. Proinflammatory. No clear association between } \\
\text { IFN- } \gamma \text { polymorphisms and PTL }\end{array}$ & {$[104,105]$} \\
\hline TNF- $\alpha$ & $-308 \mathrm{G}>\mathrm{A}$ & Th1 & $\begin{array}{l}\text { Regulatory role in PG synthesis elevated at maternal fetal interface } \\
\text { controversial link between PTL and TNF- } \alpha \text { polymorphisms }\end{array}$ & 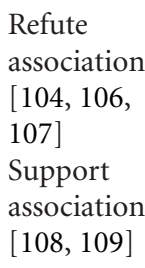 \\
\hline IL-4 & -590 & Th2 & $\begin{array}{l}\text { Classic Th2 cytokine. The IL-4 } 590 \mathrm{C} / \mathrm{C} \text { genotype is associated with } \\
\text { preterm birth but unclear. IL-4-590 SNP has been associated with } \\
\text { both low and high IL- } 4 \text { expression. Link also exists between IL-4 } \\
\text { promoter polymorphisms and preterm birth in multiple pregnancies; } \\
\text { however, polymorphism actually associated with increased IL-4 }\end{array}$ & {$[110,111]$} \\
\hline IL-10 & $\begin{array}{l}-1082 \mathrm{G}>\mathrm{A} \\
-819 \mathrm{C}>\mathrm{T} \\
-592 \mathrm{C}>\mathrm{A}\end{array}$ & Th2 & $\begin{array}{l}\text { Anti-inflammatory Th2 cytokine inhibits production of cytokines, } \\
\text { chemokines, and prostaglandins in LPS stimulated amnion, } \\
\text { choriodecidual, and placental explants [112-114]. However, no clear } \\
\text { association between IL-10 polymorphisms and PTL or adverse } \\
\text { neonatal outcome }\end{array}$ & $\begin{array}{l}{[104-} \\
106,115]\end{array}$ \\
\hline
\end{tabular}

environment. There is mounting evidence that periventricular leukomalacia and cerebral palsy are associated with fetal exposure to intra-amniotic inflammation and the development of fetal inflammatory response syndrome [128]. Thus, a strategy for targeting immune activation through the modulation of the Th1:Th2 bias may be beneficial for both the prevention of preterm labour as well as the reduction of neurological insult to the fetus.

9.1. Progesterone. There have been several studies indicating a positive response to progesterone treatment for the prevention of preterm labour in specific patient populations [129-131]. The strongest evidence for improvement in neonatal outcomes comes from the most recent multicentre randomised controlled trial which showed a $45 \%$ reduction in preterm labour ( $<33$ weeks) and a $60 \%$ reduction in respiratory distress syndrome at $<33$ weeks using $90 \mathrm{mg}$ of vaginal progesterone in women with a short cervix of $10-20 \mathrm{~mm}$ [132]. The mechanism by which progesterone contributes to pregnancy maintenance has traditionally been attributed to maintenance of uterine quiescence by increasing cyclic AMP (cAMP) and a reduction in intracellular calcium thus reducing contractility [133]. Moreover, progesterone appears to inhibit the phosphorylation of myosin, a critical step in the activation of the myometrial contractile machinery required for labour onset $[134,135]$.

Progesterone also has immunomodulatory effects on the Th1:Th2 bias. Progesterone is able to suppress Th1 differentiation and enhance Th2 differentiation in peripheral blood mononuclear cells in vitro [136]. A more potent and orally bioavailable progestogen, dydrogesterone (6-dehydro$9 \beta, 10 \alpha$-progesterone) upregulates IL-4 and downregulates IFN- $\gamma$ in PHA-stimulated PBMCs more significantly than progesterone in vitro [137]. There is also in vivo evidence of an anti-inflammatory effect of prolonged administration of vaginal progesterone. In a study of pregnant women receiving either progesterone or placebo from 24 to 34 weeks, peripheral blood leukocytes were collected before and after treatment [138]. mRNAs of the proinflammatory cytokines IL- $1 \beta$ and IL- 8 were reduced with progesterone treatment, whereas the anti-inflammatory IL-10 was increased. A multicentre placebo controlled trial (OPPTIMUM, https://www.opptimum.org.uk/: ISRCTN 14568373) powered on neonatal outcome will provide us with evidence of any potential beneficial effect of vaginal progesterone on neonates born preterm.

9.2. $N F-\kappa B$ Inhibitors. Inhibition of $N F-\kappa B$ activation is another attractive strategy to prevent preterm labour as NF$\kappa \mathrm{B}$ activation is central to the activation of labour-associated genes in labour [139]. NF- $\kappa \mathrm{B}$ activation also leads to a proinflammatory response in various cytokines including IFN- $\gamma$ [140], IL- $1 \beta$ [74], TNF- $\alpha$, and IL-8 [141]. Ex vivo studies with the anti-inflammatory sulfasalazine suppress LPS-induced IL- 6 and TNF- $\alpha$ production in fetal membranes via inhibition of translocation of p65 to the nucleus [142]. The reported clinical safety profile of sulfasalazine has been variable [143-145], however, if used in pregnancy is often supplemented with folate. The anti-inflammatory characteristics of the cyclopentenone PG, 15-deoxy- $\Delta^{12,14}$ prostaglandin $\mathrm{J}_{2}\left(15 \mathrm{dPG}_{2}\right)$ appears to be derived from its ability to inhibit NF- $\kappa$ B activation in human amnion and myometrial cell culture [146]. We have also shown that $15 \mathrm{dPGJ}_{2}$ inhibits activation of NF- $\kappa \mathrm{B}$ in human peripheral blood mononuclear cells and reduces the percentage of cells producing the proinflammatory cytokines, IFN- $\gamma$ and TNF- $\alpha$, [147]. Work conducted in our laboratory has also shown that $15 \mathrm{dPGJ}_{2}$ is able to delay labour and provide 
neuroprotection by reducing pup mortality from 75\% to 5\% in a murine model of inflammation induced preterm labour [148].

\section{Conclusion}

There has been extensive interest in the Th1:Th2 dichotomy for the maintenance of successful pregnancy. A trend towards the Th2 cytokine profile and a suppression of the Th1 cytokine profile appears to exist both in the peripheral blood but more significantly at the maternal fetal interface. Activation of the proinflammatory Th1 profile-rather than suppression of the Th2 profile-is apparent in preterm labour and thus should be considered as the logical target for immunomodulating therapies for the prevention of preterm labour and improving neonatal outcome.

\section{Acknowledgments}

L. Sykes is supported by Wellbeing of Women. P. R. Bennett and D. A. MacIntyre are supported by Imperial College Healthcare NHS Trust and the NIHR Biomedical Research Centre.

\section{References}

[1] C. Kanellopoulos-Langevin, S. M. Caucheteux, P. Verbeke, and D. M. Ojcius, "Tolerance of the fetus by the maternal immune system: role of inflammatory mediators at the fetomaternal interface," Reproductive Biology and Endocrinology, vol. 1, p. 121, 2003.

[2] L. Sykes, D. A. Maclntyre, T. G. Teoh, and P. R. Benntte, "Targeting immune activation in the prevention of preterm labour," European Obstetrics and Gynaecology, vol. 6, no. 2, pp. 100-106, 2011.

[3] A. L. V. van Nieuwenhoven, M. J. Heineman, and M. M. Faas, "The immunology of successful pregnancy," Human Reproduction Update, vol. 9, no. 4, pp. 347-357, 2003.

[4] D. Haig, "Genetic conflicts in human pregnancy," The Quarterly Review of Biology, vol. 68, no. 4, pp. 495-532, 1993.

[5] O. Thellin and E. Heinen, "Pregnancy and the immune system: between tolerance and rejection," Toxicology, vol. 185, no. 3, pp. 179-184, 2003.

[6] P. Luppi, "How immune mechanisms are affected by pregnancy," Vaccine, vol. 21, no. 24, pp. 3352-3357, 2003.

[7] K. M. Aagaard-Tillery, R. Silver, and J. Dalton, "Immunology of normal pregnancy," Seminars in Fetal and Neonatal Medicine, vol. 11, no. 5, pp. 279-295, 2006.

[8] P. B. Medawar, "Some immunological and endocrinological problems raised by the evolution of viviparity in vertebrates," Symposia of the Society for Experimental Biology, vol. 7, pp. 320-338, 1953.

[9] M. Kuhnert, R. Strohmeier, M. Stegmüller, and E. Halberstadt, "Changes in lymphocyte subsets during normal pregnancy," European Journal of Obstetrics Gynecology and Reproductive Biology, vol. 76, no. 2, pp. 147-151, 1998.

[10] V. R. Aluvihare, M. Kallikourdis, and A. G. Betz, "Regulatory T cells mediate maternal tolerance to the fetus," Nature Immunology, vol. 5, no. 3, pp. 266-271, 2004.

[11] S. Saito, A. Nakashima, T. Shima, and M. Ito, "Th1/Th2/Th17 and regulatory T-cell paradigm in pregnancy," American
Journal of Reproductive Immunology, vol. 63, no. 6, pp. 601610, 2010.

[12] G. Chaouat, "Regulation of T-cell activities at the fetoplacental interface-by placenta?" American Journal of Reproductive Immunology, vol. 42, no. 4, pp. 199-204, 1999.

[13] K. Koga and G. Mor, "Toll-like receptors at the maternal-fetal interface in normal pregnancy and pregnancy disorders," American Journal of Reproductive Immunology, vol. 63, no. 6, pp. 587-600, 2010.

[14] E. Lorenz, J. P. Mira, K. L. Frees, and D. A. Schwartz, "Relevance of mutations in the TLR4 receptor in patients with gram-negative septic shock," Archives of Internal Medicine, vol. 162, no. 9, pp. 1028-1032, 2002.

[15] T. G. Krediet, S. P. Wiertsema, M. J. Vossers et al., "Toll-like receptor 2 polymorphism is associated with preterm birth," Pediatric Research, vol. 62, no. 4, pp. 474-476, 2007.

[16] M. P. Piccinni, M. G. Giudizi, R. Biagiotti et al., "Progesterone favors the development of human T helper cells producing Th2- type cytokines and promotes both IL-4 production and membrane CD30 expression in established Th1 cell clones," Journal of Immunology, vol. 155, no. 1, pp. 128-133, 1995.

[17] J. Trowsdale and A. G. Betz, "Mother's little helpers: mechanisms of maternal-fetal tolerance," Nature Immunology, vol. 7, no. 3, pp. 241-246, 2006.

[18] S. A. Huber, J. Kupperman, and M. K. Newell, "Estradiol prevents and testosterone promotes Fas-dependent apoptosis in CD4+ Th2 cells by altering Bcl 2 expression," Lupus, vol. 8, no. 5, pp. 384-387, 1999.

[19] L. Xue, S. L. Gyles, F. R. Wettey et al., "Prostaglandin D2 causes preferential induction of proinflammatory Th2 cytokine production through an action on chemoattractant receptor-like molecule expressed on Th2 cells," Journal of Immunology, vol. 175, no. 10, pp. 6531-6536, 2005.

[20] A. Rao and O. Avni, "Molecular aspects of T-cell differentiation," British Medical Bulletin, vol. 56, no. 4, pp. 969-984, 2000.

[21] T. R. Mosmann and R. L. Coffman, "TH1 and TH2 cells: different patterns of lymphokine secretion lead to different functional properties," Annual Review of Immunology, vol. 7, pp. 145-173, 1989.

[22] J. R. Wilczynski, “Th1/Th2 cytokines balance-yin and yang of reproductive immunology," European Journal of Obstetrics \& Gynecology and Reproductive Biology, vol. 122, no. 2, pp. 136-143, 2005.

[23] M. P. Piccinni, "T cells in normal pregnancy and recurrent pregnancy loss," Reproductive BioMedicine Online, vol. 13, no. 6, pp. 840-844, 2006.

[24] A. O'Garra and N. Arai, "The molecular basis of T helper 1 and T helper 2 cell differentiation," Trends in Cell Biology, vol. 10, no. 12, pp. 542-550, 2000.

[25] C. Marie, C. Pitton, C. Fitting, and J. M. Cavaillon, "Regulation by anti-inflammatory cytokines (IL-4, IL-10, IL-13, TGF $\beta$ ) of interleukin- 8 production by LPS- and/or TNF $\alpha$ activated human polymorphonuclear cells," Mediators of Inflammation, vol. 5, no. 5, pp. 334-340, 1996.

[26] P. C. Greig, A. P. Murtha, C. J. Jimmerson, W. N. P. Herbert, B. Roitman-Johnson, and J. Allen, "Maternal serum interleukin-6 during pregnancy and during term and preterm labor," Obstetrics and Gynecology, vol. 90, no. 3, pp. 465469, 1997.

[27] R. Druckmann and M. A. Druckmann, "Progesterone and the immunology of pregnancy," Journal of Steroid Biochemistry and Molecular Biology, vol. 97, no. 5, pp. 389-396, 2005. 
[28] T. Michimata, H. Tsuda, M. Sakai et al., "Accumulation of CRTH2-positive T-helper 2 and T-cytotoxic 2 cells at implantation sites of human decidua in a prostaglandin D2mediated manner," Molecular Human Reproduction, vol. 8, no. 2, pp. 181-187, 2002.

[29] D. F. Fiorentino, M. W. Bond, and T. R. Mosmann, "Two types of mouse T helper cell. IV. Th2 clones secrete a factor that inhibits cytokine production by Th1 clones," Journal of Experimental Medicine, vol. 170, no. 6, pp. 2081-20095, 1989.

[30] A. E. Chernoff, E. V. Granowitz, L. Shapiro et al., "A randomized, controlled trial of IL-10 in humans: inhibition of inflammatory cytokine production and immune responses," Journal of Immunology, vol. 154, no. 10, pp. 5492-5499, 1995.

[31] F. Belardelli, "Role of interferons and other cytokines in the regulation of the immune response," APMIS, vol. 103, no. 3, pp. 161-179, 1995.

[32] R. Raghupathy, "Th1-type immunity is incompatible with successful pregnancy," Immunology Today, vol. 18, no. 10, pp. 478-482, 1997.

[33] A. O'Garra and P. Vieira, "TH1 cells control themselves by producing interleukin-10," Nature Reviews Immunology, vol. 7, no. 6, pp. 425-428, 2007.

[34] R. Sabat, G. Grütz, K. Warszawska et al., "Biology of interleukin-10," Cytokine and Growth Factor Reviews, vol. 21, no. 5, pp. 331-344, 2010.

[35] T. Kishimoto, "Interleukin-6: from basic science to medicine-40 Years in immunology," Annual Review of Immunology, vol. 23, pp. 1-21, 2005.

[36] T. R. Mosmann and S. Sad, "The expanding universe of T-cell subsets: Th1, Th2 and more," Immunology Today, vol. 17, no. 3, pp. 138-146, 1996.

[37] M. P. Piccinni, "Role of immune cells in pregnancy," Autoimmunity, vol. 36, no. 1, pp. 1-4, 2003.

[38] A. Sher and R. L. Coffman, "Regulation of immunity to parasites by T cells and T cell-derived cytokines," Annual Review of Immunology, vol. 10, pp. 385-409, 1992.

[39] M. P. Piccinni, C. Scaletti, E. Maggi, and S. Romagnani, "Role of hormone-controlled Th1- and Th2-type cytokines in successful pregnancy," Journal of Neuroimmunology, vol. 109, no. 1, pp. 30-33, 2000.

[40] S. J. Szabo, L. H. Glimcher, and I. C. Ho, "Genes that regulate interleukin-4 expression in T cells," Current Opinion in Immunology, vol. 9, no. 6, pp. 776-781, 1997.

[41] T. G. Wegmann, H. Lin, L. Guilbert, and T. R. Mosmann, "Bidirectional cytokine interactions in the maternal-fetal relationship: is successful pregnancy a TH2 phenomenon?" Immunology Today, vol. 14, no. 7, pp. 353-356, 1993.

[42] G. Chaouat, A. A. Meliani, J. Martal et al., "IL-10 prevents naturally occuring fetal loss in the CBA $x \mathrm{DBA} / 2$ mating combination, and local defect in IL-10 production in this abortion-prone combination is corrected by in vivo injection of IFN- $\tau$," Journal of Immunology, vol. 154, no. 9, pp. 42614268, 1995.

[43] D. A. Clark, G. Chaouat, P. C. Arck, H. W. Mittruecker, and G. A. Levy, "Cytokine-dependent abortion in CBA x DBA/2 mice is mediated by the procoagulant fgl2 prothrombinase [correction of prothombinase]," Journal of Immunology, vol. 160, no. 2, pp. 545-549, 1998.

[44] M. Østensen and P.M. Villiger, "Immunology of pregnancypregnancy as a remission inducing agent in rheumatoid arthritis," Transplant Immunology, vol. 9, no. 2-4, pp. 155160, 2001.
[45] E. Märker-Hermann and R. Fischer-Betz, "Rheumatic diseases and pregnancy," Current Opinion in Obstetrics and Gynecology, vol. 22, no. 6, pp. 458-465, 2010.

[46] J. A. Poole and H. N. Claman, "Immunology of pregnancy: implications for the mother," Clinical Reviews in Allergy and Immunology, vol. 26, no. 3, pp. 161-170, 2004.

[47] M. Marzi, A. Vigano, D. Trabattoni et al., "Characterization of type 1 and type 2 cytokine production profile in physiologic and pathologic human pregnancy," Clinical and Experimental Immunology, vol. 106, no. 1, pp. 127-133, 1996.

[48] G. Reinhard, A. Noll, H. Schlebusch, P. Mallmann, and A. V. Ruecker, "Shifts in the TH1/TH2 balance during human pregnancy correlate with apoptotic changes," Biochemical and Biophysical Research Communications, vol. 245, no. 3, pp. 933-938, 1998.

[49] J. Tranchot-Diallo, G. Gras, F. Parnet-Mathieu et al., "Modulations of cytokine expression in pregnant women," American Journal of Reproductive Immunology, vol. 37, no. 3, pp. 215226, 1997.

[50] Y. Shimaoka, Y. Hidaka, H. Tada et al., "Changes in cytokine production during and after normal pregnancy," American Journal of Reproductive Immunology, vol. 44, no. 3, pp. 143$147,2000$.

[51] L. Matthiesen, C. Ekerfelt, G. Berg, and J. Ernerudh, "Increased numbers of circulating interferon- $\gamma$ - and interleukin-4-secreting cells during normal pregnancy," American Journal of Reproductive Immunology, vol. 39, no. 6, pp. 362367, 1998.

[52] L. Matthiesen, M. Khademi, C. Ekerfelt et al., "In-situ detection of both inflammatory and anti-inflammatory cytokines in resting peripheral blood mononuclear cells during pregnancy," Journal of Reproductive Immunology, vol. 58, no. 1, pp. 49-59, 2003.

[53] G. B. Dealtry, D. E. Clark, A. Sharkey, D. S. Charnock-Jones, and S. K. Smith, "VII international congress of reproductive immunology, New Delhi, 27-30 October 1998: expression and localization of the Th2-type cytokine interleukin-13 and its receptor in the placenta during human pregnancy," American Journal of Reproductive Immunology, vol. 40, no. 4, pp. 283-290, 1998.

[54] I. Roth, D. B. Corry, R. M. Locksley, J. S. Abrams, M. J. Litton, and S. J. Fisher, "Human placental cytotrophoblasts produce the immunosuppressive cytokine interleukin 10," Journal of Experimental Medicine, vol. 184, no. 2, pp. 539-548, 1996.

[55] C. A. Jones, J. J. Finlay-Jones, and P. H. Hart, "Type-1 and type-2 cytokines in human late-gestation decidual tissue," Biology of Reproduction, vol. 57, no. 2, pp. 303-311, 1997.

[56] W. A. Bennett, S. Lagoo-Deenadayalan, M. N. Brackin, E. Hale, and B. D. Cowan, "Cytokine expression by models of human trophoblast as assessed by a semiquantitative reverse transcription-polymerase chain reaction technique," American Journal of Reproductive Immunology, vol. 36, no. 5, pp. 285-294, 1996.

[57] F. Liu, J. Guo, T. Tian et al., "Placental trophoblasts shifted Th1/Th2 balance toward Th2 and inhibited Th17 immunity at fetomaternal interface," APMIS, 2011.

[58] T. Michimata, M. Sakai, S. Miyazaki et al., "Decrease of Thelper 2 and T-cytotoxic 2 cells at implantation sites occurs in unexplained recurrent spontaneous abortion with normal chromosomal content," Human Reproduction, vol. 18, no. 7, pp. 1523-1528, 2003.

[59] M. P. Piccinni, "T cell tolerance towards the fetal allograft," Journal of Reproductive Immunology, vol. 85, no. 1, pp. 71$75,2010$. 
[60] S. J. Fortunato, R. Menon, and S. J. Lombardi, "Interleukin10 and transforming growth factor- $\beta$ inhibit amniochorion tumor necrosis factor- $\alpha$ production by contrasting mechanisms of action: therapeutic implications in prematurity," American Journal of Obstetrics and Gynecology, vol. 177, no. 4, pp. 803-809, 1997.

[61] J. S. Gilmour, W. R. Hansen, H. C. Miller, J. A. Keelan, T. A. Sato, and M. D. Mitchell, "Effects of interleukin-4 on the expression and activity of prostaglandin endoperoxide $\mathrm{H}$ synthase-2 in amnion-derived WISH cells," Journal of Molecular Endocrinology, vol. 21, no. 3, pp. 317-325, 1998.

[62] J. A. Keelan, T. A. Sato, and M. D. Mitchell, "Comparative studies on the effects of interleukin-4 and interleukin-13 on cytokine and prostaglandin E2 production by amnionderived WISH cells," American Journal of Reproductive Immunology, vol. 40, no. 5, pp. 332-338, 1998.

[63] K. Bry and U. Lappalainen, "Interleukin-4 and transforming growth factor- $\beta 1$ modulate the production of interleukin1 receptor antagonist and of prostaglandin E2 by decidual cells," American Journal of Obstetrics and Gynecology, vol. 170, no. 4, pp. 1194-1198, 1994.

[64] V. J. Goodwin, T. A. Sato, M. D. Mitchell, and J. A. Keelan, "Anti-inflammatory effects of interleukin-4, interleukin-10, and transforming growth factor- $\beta$ on human placental cells in vitro," American Journal of Reproductive Immunology, vol. 40, no. 5, pp. 319-325, 1998.

[65] M. P. Piccinni, L. Beloni, C. Livi, E. Maggi, G. Scarselli, and S. Romagnani, "Defective production of both leukemia inhibitory factor and type $2 \mathrm{~T}$ - helper cytokines by decidual T cells in unexplained recurrent abortions," Nature Medicine, vol. 4, no. 9, pp. 1020-1024, 1998.

[66] S. Saito, M. Sakai, Y. Sasaki, K. Tanebe, H. Tsuda, and T. Michimata, "Quantitative analysis of peripheral blood Th0, Th1, Th2 and the Th1:Th2 cell ratio during normal human pregnancy and preeclampsia," Clinical and Experimental Immunology, vol. 117, no. 3, pp. 550-555, 1999.

[67] T. Kuwajima, S. Suzuki, R. Sawa, Y. Yoneyama, T. Takeshita, and T. Araki, "Changes in maternal peripheral T helper 1type and T helper 2-type immunity during labor," Tohoku Journal of Experimental Medicine, vol. 194, no. 2, pp. 137$140,2001$.

[68] A. E. Omu, F. Al-Qattan, M. E. Diejomaoh, and M. AlYatama, "Differential levels of $\mathrm{T}$ helper cytokines in preeclampsia: pregnancy, labor and puerperium," Acta Obstetricia et Gynecologica Scandinavica, vol. 78, no. 8, pp. 675-680, 1999.

[69] G. Buonocore, M. De Filippo, D. Gioia et al., "Maternal and neonatal plasma cytokine levels in relation to mode of delivery," Biology of the Neonate, vol. 68, no. 2, pp. 104-110, 1995.

[70] C. L. Elliott, J. A. Z. Loudon, N. Brown, D. M. Slater, P. R. Bennett, and M. H. F. Sullivan, "IL- $1 \beta$ and IL- 8 in human fetal membranes: changes with gestational age, labor, and culture conditions," American Journal of Reproductive Immunology, vol. 46, no. 4, pp. 260-267, 2001.

[71] J. A. Keelan, K. W. Marvin, T. A. Sato, M. Coleman, L. M. E. McCowan, and M. D. Mitchell, "Cytokine abundance in placental tissues: evidence of inflammatory activation in gestational membranes with term and preterm parturition," American Journal of Obstetrics and Gynecology, vol. 181, no. 6, pp. 1530-1536, 1999.

[72] N. P. Maulén, E. A. Henríquez, S. Kempe et al., "Upregulation and polarized expression of the sodium-ascorbic acid transporter SVCT1 in post-confluent differentiated
CaCo-2 cells," Journal of Biological Chemistry, vol. 278, no. 11, pp. 9035-9041, 2003.

[73] T. M. Lindström and P. R. Bennett, "15-Deoxy- $\delta 12,14-$ prostaglandin $\mathrm{J} 2$ inhibits interleukin- $\beta$-induced nuclear factor- $\kappa \mathrm{B}$ in human amnion and myometrial cells: mechanisms and implications," Journal of Clinical Endocrinology and Metabolism, vol. 90, no. 6, pp. 3534-3543, 2005.

[74] T. M. Lindström and P. R. Bennett, "The role of nuclear factor kappa B in human labour," Reproduction, vol. 130, no. 5, pp. 569-581, 2005.

[75] J. A. Keelan, M. Blumenstein, R. J. A. Helliwell, T. A. Sato, K. W. Marvin, and M. D. Mitchell, "Cytokines, prostaglandins and parturition-a review," Placenta, vol. 24, supplement A, pp. S33-S46, 2003.

[76] J. A. Keelan, T. A. Sato, W. R. Hansen et al., "Interleukin-4 differentially regulates prostaglandin production in amnionderived WISH cells stimulated with pro-inflammatory cytokines and epidermal growth factor," Prostaglandins Leukotrienes and Essential Fatty Acids, vol. 60, no. 4, pp. 255262, 1999.

[77] J. K. Pollard, D. Thai, and M. D. Mitchell, "Mechanism of cytokine stimulation of prostaglandin biosynthesis in human decidua," Journal of the Society for Gynecologic Investigation, vol. 1, no. 1, pp. 31-36, 1994.

[78] C. Infante-Duarte and T. Kamradt, "Th1/Th2 balance in infection," Springer Seminars in Immunopathology, vol. 21, no. 3, pp. 317-338, 1999.

[79] D. H. Libraty, L. E. Airan, K. Uyemura et al., "Interferon$\gamma$ differentially regulates interleukin-12 and interleukin- 10 production in leprosy," Journal of Clinical Investigation, vol. 99, no. 2, pp. 336-341, 1997.

[80] Y. Lin, M. Zhang, F. M. Hofman, J. Gong, and P. F. Barnes, "Absence of a prominent Th2 cytokine response in human tuberculosis," Infection and Immunity, vol. 64, no. 4, pp. 1351-1356, 1996.

[81] C. S. Tripp, S. F. Wolf, and E. R. Unanue, "Interleukin 12 and tumor necrosis factor $\alpha$ are costimulators of interferon $\gamma$ production by natural killer cells in severe combined immunodeficiency mice with listeriosis, and interleukin 10 is a physiologic antagonist," Proceedings of the National Academy of Sciences of the United States of America, vol. 90, no. 8, pp. 3725-3729, 1993.

[82] H. M. Surcel, M. Troye-Blomberg, S. Paulie et al., "Th1/Th2 profiles in tuberculosis, based on the proliferation and cytokine response of blood lymphocytes to mycobacterial antigens," Immunology, vol. 81, no. 2, pp. 171-176, 1994.

[83] S. E. Macatonia, N. A. Hosken, M. Litton et al., "Dendritic cells produce IL-12 and direct the development of Th1 cells from naive CD4+ T cells," Journal of Immunology, vol. 154, no. 10, pp. 5071-5079, 1995.

[84] C. S. Hsieh, S. E. Macatonia, C. S. Tripp, S. F. Wolf, A. O'Garra, and K. M. Murphy, "Development of T(H)1 CD4+ T cells through IL-12 produced by Listeria-induced macrophages," Science, vol. 260, no. 5107, pp. 547-549, 1993.

[85] A. O'Garra, "Cytokines induce the development of functionally heterogeneous T helper cell subsets," Immunity, vol. 8, no. 3, pp. 275-283, 1998.

[86] L. M. Hollier, M. K. Rivera, E. Henninger, L. C. Gilstrap, and G. D. Marshall, "T helper cell cytokine profiles in preterm labor," American Journal of Reproductive Immunology, vol. 52, no. 3, pp. 192-196, 2004.

[87] S. A. McCracken, E. Gallery, and J. M. Morris, "Pregnancyspecific down-regulation of NF- $\kappa \mathrm{B}$ expression in $\mathrm{T}$ cells in 
humans is essential for the maintenance of the cytokine profile required for pregnancy success," Journal of Immunology, vol. 172, no. 7, pp. 4583-4591, 2004.

[88] M. R. Goldberg, O. Nadiv, N. Luknar-Gabor, G. ZadikMnuhin, J. Tovbin, and Y. Katz, "Correlation of Th1type cytokine expression and induced proliferation to lipopolysaccharide," American Journal of Respiratory Cell and Molecular Biology, vol. 38, no. 6, pp. 733-737, 2008.

[89] T. Matsuoka, T. Matsubara, K. Katayama, K. Takeda, M. Koga, and S. Furukawa, "Increase of cord blood cytokineproducing T cells in intrauterine infection," Pediatrics International, vol. 43, no. 5, pp. 453-457, 2001.

[90] F. C. Denison, R. W. Kelly, A. A. Calder, and S. C. Riley, "Cytokine secretion by human fetal membranes, decidua and placenta at term," Human Reproduction, vol. 13, no. 12, pp. 3560-3565, 1998.

[91] G. Griesinger, L. Saleh, S. Bauer, P. Husslein, and M. Knöfler, "Production of pro- and anti-inflammatory cytokines of human placental trophoblasts in response to pathogenic bacteria," Journal of the Society for Gynecologic Investigation, vol. 8, no. 6, pp. 334-340, 2001.

[92] J. R. G. Challis, "Mechanism of parturition and preterm labor," Obstetrical and Gynecological Survey, vol. 55, no. 10, pp. 650-660, 2000.

[93] R. L. Goldenberg, W. W. Andrews, and J. C. Hauth, "Choriodecidual infection and preterm birth," Nutrition Reviews, vol. 60, no. 5, pp. S19-S25, 2002.

[94] A. E. Curry, I. Vogel, C. Drews et al., "Mid-pregnancy maternal plasma levels of interleukin 2, 6, and 12, tumor necrosis factor- $\alpha$, interferon-gamma, and granulocyte-macrophage colony-stimulating factor and spontaneous preterm delivery," Acta Obstetricia et Gynecologica Scandinavica, vol. 86, no. 9, pp. 1103-1110, 2007.

[95] A. M. Bahar, H. W. Ghalib, R. A. Moosa, Z. M. S. Zaki, C. Thomas, and O. A. Nabri, "Maternal serum interleukin-6, interleukin-8, tumor necrosis factor- $\alpha$ and interferon- $\gamma$, in preterm labor," Acta Obstetricia et Gynecologica Scandinavica, vol. 82, no. 6, pp. 543-549, 2003.

[96] R. Raghupathy, M. Makhseed, S. El-Shazly, F. Azizieh, R. Farhat, and L. Ashkanani, "Cytokine patterns in maternal blood after premature rupture of membranes," Obstetrics and Gynecology, vol. 98, no. 1, pp. 122-126, 2001.

[97] M. Makhseed, R. Raghupathy, S. El-Shazly, F. Azizieh, J. A. Al-Harmi, and M. M. K. Al-Azemi, "Pro-inflammatory maternal cytokine profile in preterm delivery," American Journal of Reproductive Immunology, vol. 49, no. 5, pp. 308318, 2003.

[98] C. K. Ekelund, I. Vogel, K. Skogstrand et al., "Interleukin18 and interleukin-12 in maternal serum and spontaneous preterm delivery," Journal of Reproductive Immunology, vol. 77, no. 2, pp. 179-185, 2008.

[99] S. Q. Wei, W. Fraser, and Z. C. Luo, "Inflammatory cytokines and spontaneous preterm birth in asymptomatic women: a systematic review," Obstetrics and Gynecology, vol. 116, no. 2, pp. 393-401, 2010.

[100] S. El-Shazly, M. Makhseed, F. Azizieh, and R. Raghupathy, "Increased expression of pro-inflammatory cytokines in placentas of women undergoing spontaneous preterm delivery of premature rupture of membranes," American Journal of Reproductive Immunology, vol. 52, no. 1, pp. 45-52, 2004.

[101] F. Ni Chuileannain and S. Brennecke, "Prediction of preterm labour in multiple pregnancies," Bailliere's Clinical Obstetrics and Gynaecology, vol. 12, no. 1, pp. 53-66, 1998.
[102] S. J. Fortunato, R. Menon, and S. J. Lombardi, "Role of tumor necrosis factor- $\alpha$ in the premature rupture of membranes and preterm labor pathways," American Journal of Obstetrics and Gynecology, vol. 187, no. 5, pp. 1159-1162, 2002.

[103] M. L. Casey, S. M. Cox, B. Beutler, L. Milewich, and P. C. MacDonald, "Cachectin/tumor necrosis factor- $\alpha$ formation in human decidua. Potential role of cytokines in infectioninduced preterm labor," Journal of Clinical Investigation, vol. 83, no. 2, pp. 430-436, 1989.

[104] R. Mattar, E. de Souza, and S. Daher, "Preterm delivery and cytokine gene polymorphisms," Journal of Reproductive Medicine, vol. 51, no. 4, pp. 317-320, 2006.

[105] E. Moura, R. Mattar, E. de Souza, M. R. Torloni, A. Goncalves-Primo, and S. Daher, "Inflammatory cytokine gene polymorphisms and spontaneous preterm birth," Journal of Reproductive Immunology, vol. 80, no. 1-2, pp. 115-121, 2009.

[106] M. Nuk, K. Orendi, S. Rosenberger et al., "Genetic variations in fetal and maternal tumor necrosis factor- $\alpha$ and interleukin 10: is there an association with preterm birth or periventricular leucomalacia?" Journal of Perinatology, vol. 32, no. 1, pp. 27-32, 2012.

[107] R. Menon, M. Merialdi, A. P. Betran et al., "Analysis of association between maternal tumor necrosis factor- $\alpha$ promoter polymorphism (-308), tumor necrosis factor concentration, and preterm birth," American Journal of Obstetrics and Gynecology, vol. 195, no. 5, pp. 1240-1248, 2006.

[108] G. A. Macones, S. Parry, M. Elkousy, B. Clothier, S. H. Ural, and J. F. Strauss III, "A polymorphism in the promoter region of TNF and bacterial vaginosis: preliminary evidence of gene-environment interaction in the etiology of spontaneous preterm birth," American Journal of Obstetrics and Gynecology, vol. 190, no. 6, pp. 1504-1508, 2004.

[109] S. Moore, M. Ide, M. Randhawa, J. J. Walker, J. G. Reid, and N. A. B. Simpson, "An investigation into the association among preterm birth, cytokine gene polymorphisms and periodontal disease," International Journal of Obstetrics and Gynaecology, vol. 111, no. 2, pp. 125-132, 2004.

[110] M. F. Annells, P. H. Hart, C. G. Mullighan et al., "Interleukins-1, -4, -6, -10, tumor necrosis factor, transforming growth factor- $\beta$, FAS, and mannose-binding protein $C$ gene polymorphisms in Australian women: risk of preterm birth," American Journal of Obstetrics and Gynecology, vol. 191, no. 6, pp. 2056-2067, 2004.

[111] R. B. Kalish, S. Vardhana, M. Gupta, S. C. Perni, and S. S. Witkin, "Interleukin-4 and -10 gene polymorphisms and spontaneous preterm birth in multifetal gestations," American Journal of Obstetrics and Gynecology, vol. 190, no. 3, pp. 702-706, 2004.

[112] T. A. Sato, J. A. Keelan, and M. D. Mitchell, "Critical paracrine interactions between TNF- $\alpha$ and IL-10 regulate lipopolysaccharide-stimulated human choriodecidual cytokine and prostaglandin E2 production," Journal of Immunology, vol. 170, no. 1, pp. 158-166, 2003.

[113] N. L. Brown, S. A. Alvi, M. G. Elder, P. R. Bennett, and M. H. F. Sullivan, "The regulation of prostaglandin output from term intact fetal membranes by anti-inflammatory cytokines," Immunology, vol. 99, no. 1, pp. 124-133, 2000.

[114] N. Hanna, L. Bonifacio, B. Weinberger et al., "Evidence for interleukin-10-mediated inhibition of cyclo-oxygenase-2 expression and prostaglandin production in preterm human placenta," American Journal of Reproductive Immunology, vol. 55 , no. 1, pp. 19-27, 2006. 
[115] K. Yanamandra, P. Boggs, J. Loggins, and R. J. Baier, "Interleukin-10 -1082 G/A polymorphism and risk of death or bronchopulmonary dysplasia in ventilated very low birth weight infants," Pediatric Pulmonology, vol. 39, no. 5, pp. 426-432, 2005.

[116] D. G. Remick, "Interleukin-8," Critical Care Medicine, vol. 33, supplement 12, pp. S466-S467, 2005.

[117] T. J. Standiford, S. L. Kunkel, M. A. Basha et al., "Interleukin8 gene expression by a pulmonary epithelial cell line. A model for cytokine networks in the lung," Journal of Clinical Investigation, vol. 86, no. 6, pp. 1945-1953, 1990.

[118] K. W. Marvin, J. A. Keelan, R. L. Eykholt, T. A. Sato, and M. D. Mitchell, "Use of cDNA array to generate differential expression profiles for inflammatory genes in human gestational membranes delivered at term and preterm," Molecular Human Reproduction, vol. 8, no. 4, pp. 399-408, 2002.

[119] S. Bollopragada, R. Youssef, F. Jordan, I. Greer, J. Norman, and S. Nelson, "Term labor is associated with a core inflammatory response in human fetal membranes, myometrium, and cervix," American Journal of Obstetrics and Gynecology, vol. 200, no. 1, pp. 104.e1-104.e11, 2009.

[120] E. C. Chan, S. Fraser, S. Yin et al., "Human myometrial genes are differentially expressed in labor: a suppression subtractive hybridization study," Journal of Clinical Endocrinology and Metabolism, vol. 87, no. 6, pp. 2435-2441, 2002.

[121] Y. Sorokin, R. Romero, L. Mele et al., "Maternal serum interleukin-6, c-reactive protein, and matrix metalloproteinase- 9 concentrations as risk factors for preterm birth $<32$ weeks and adverse neonatal outcomes," American Journal of Perinatology, vol. 27, no. 8, pp. 631-639, 2010.

[122] R. Romero, M. Mazor, H. Munoz, R. Gomez, M. Galasso, and D. M. Sherer, "The preterm labor syndrome," Annals of the New York Academy of Sciences, vol. 734, pp. 414-429, 1994.

[123] R. Romero, R. Gomez, M. Galasso et al., "Macrophage inflammatory protein- $1 \alpha$ in term and preterm parturition: effect of microbial invasion of the amniotic cavity," American Journal of Reproductive Immunology, vol. 32, no. 2, pp. 108113, 1994.

[124] R. Romero, B. H. Yoon, M. Mazor et al., "A comparative study of the diagnostic performance of amniotic fluid glucose, white blood cell count, interleukin-6, and Gram stain in the detection of microbial invasion in patients with preterm premature rupture of membranes," American Journal of Obstetrics and Gynecology, vol. 169, no. 4, pp. 839-851, 1993.

[125] B. H. Yoon, R. Romero, J. S. Park et al., "Fetal exposure to an intra-amniotic inflammation and the development of cerebral palsy at the age of three years," American Journal of Obstetrics and Gynecology, vol. 182, no. 3, pp. 675-681, 2000.

[126] A. Heep, D. Behrendt, P. Nitsch, R. Fimmers, P. Bartmann, and J. Dembinski, "Increased serum levels of interleukin 6 are associated with severe intraventricular haemorrhage in extremely premature infants," Archives of Disease in Childhood, vol. 88, no. 6, pp. F501-F504, 2003.

[127] R. L. Goldenberg, "The management of preterm labor," Obstetrics and Gynecology, vol. 100, no. 5, pp. 1020-1037, 2002.

[128] B. H. Yoon, C. W. Park, and T. Chaiworapongsa, "Intrauterine infection and the development of cerebral palsy," International Journal of Obstetrics and Gynaecology, vol. 110, supplement 20, pp. 124-127, 2003.

[129] P. J. Meis, M. Klebanoff, E. Thom et al., "Prevention of recurrent preterm delivery by $17 \alpha$-hydroxyprogesterone caproate," New England Journal of Medicine, vol. 348, no. 24, pp. 2379-2385, 2003.
[130] E. B. Da Fonseca, R. E. Bittar, M. H. B. Carvalho, and M. Zugaib, "Prophylactic administration of progesterone by vaginal suppository to reduce the incidence of spontaneous preterm birth in women at increased risk: a randomized placebo-controlled double-blind study," American Journal of Obstetrics and Gynecology, vol. 188, no. 2, pp. 419-424, 2003.

[131] E. B. Fonseca, E. Celik, M. Parra, M. Singh, and K. H. Nicolaides, "Progesterone and the risk of preterm birth among women with a short cervix," New England Journal of Medicine, vol. 357, no. 5, pp. 462-469, 2007.

[132] S. S. Hassan, R. Romero, D. Vidyadhari et al., "Vaginal progesterone reduces the rate of preterm birth in women with a sonographic short cervix: a multicenter, randomized, double-blind, placebo-controlled trial," Ultrasound in Obstetrics and Gynecology, vol. 38, no. 1, pp. 18-31, 2011.

[133] M. S. Soloff, Y. J. Jeng, M. G. Izban et al., "Effects of progesterone treatment on expression of genes involved in uterine quiescence," Reproductive Sciences, vol. 18, no. 8, pp. 781-797, 2011.

[134] C. H. Egarter and P. Husslein, "Biochemistry of myometrial contractibly," Bailliere's Clinical Obstetrics and Gynaecology, vol. 6, no. 4, pp. 755-769, 1992.

[135] D. A. MacIntyre, E. C. Chan, and R. Smith, "Myometrial activation-coordination, connectivity and contractility," Fetal and Maternal Medicine Review, vol. 18, no. 4, pp. 333356, 2007.

[136] H. Miyaura and M. Iwata, "Direct and indirect inhibition of Th1 development by progesterone and glucocorticoids," Journal of Immunology, vol. 168, no. 3, pp. 1087-1094, 2002.

[137] R. Raghupathy, E. Al Mutawa, M. Makhseed, M. Al-azemi, and F. Azizieh, "Redirection of cytokine production by lymphocytes from women with pre-term delivery by dydrogesterone," American Journal of Reproductive Immunology, vol. 58, no. 1, pp. 31-38, 2007.

[138] J. E. Norman, M. Yuan, L. Anderson et al., "Effect of prolonged in vivo administration of progesterone in pregnancy on myometrial gene expression, peripheral blood leukocyte activation, and circulating steroid hormone levels," Reproductive Sciences, vol. 18, no. 5, pp. 435-446, 2011.

[139] T. M. Lindström and P. R. Bennett, "The role of nuclear factor kappa B in human labour," Reproduction, vol. 130, no. 5, pp. 569-581, 2005.

[140] W. Lai, M. Yu, M. N. Huang, F. Okoye, A. D. Keegan, and D. L. Farber, "Transcriptional control of rapid recall by memory CD4 T cells," Journal of Immunology, vol. 187, no. 1, pp. 133140, 2011.

[141] A. R. Mohan, J. A. Loudon, and P. R. Bennett, "Molecular and biochemical mechanisms of preterm labour," Seminars in Fetal and Neonatal Medicine, vol. 9, no. 6, pp. 437-444, 2004.

[142] J. A. Keelan, S. Khan, F. Yosaatmadja, and M. D. Mitchell, "Prevention of inflammatory activation of human gestational membranes in an ex vivo model using a pharmacological NF- $\kappa$ B inhibitor," Journal of Immunology, vol. 183, no. 8, pp. 5270-5278, 2009.

[143] W. Connell and A. Miller, "Treating inflammatory bowel disease during pregnancy. Risks and safety of drug therapy," Drug Safety, vol. 21, no. 4, pp. 311-323, 1999.

[144] S. Ishaq and J. R. B. Green, "Tolerability of aminosalicylates in inflammatory bowel disease," BioDrugs, vol. 15, no. 5, pp. 339-349, 2001.

[145] B. Norgard, L. Pedersen, L. A. Christensen, and H. T. Sørensen, "Therapeutic drug use in women with crohn's 
disease and birth outcomes: a danish nationwide cohort study," American Journal of Gastroenterology, vol. 102, no. 7, pp. 1406-1413, 2007.

[146] T. M. Lindström and P. R. Bennett, "15-Deoxy- $\delta 12,14-$ prostaglandin $\mathrm{J} 2$ inhibits interleukin- $1 \beta$-induced nuclear factor- $\kappa \mathrm{B}$ in human amnion and myometrial cells: mechanisms and implications," Journal of Clinical Endocrinology and Metabolism, vol. 90, no. 6, pp. 3534-3543, 2005.

[147] L. Sykes, D. MacIntyre, X. J. Yap, S. Ponnampalam, T. G. Teoh, and P. R. Bennett, "Changes in the Th1:Th2 cytokine bias in pregnancy and the effects of the anti-inflammatory cyclopentenone prostaglandin 15 -deoxy- $\Delta^{12,14}$ Prostaglandin $\mathrm{J}_{2}$," Mediators of Inflammation, vol. 2012, Article ID 416739, 2012.

[148] G. Pirianov, S. N. Waddington, T. M. Lindstrom, V. Terzidou, H. Mehmet, and P. R. Bennett, "The cyclopentenone 15deoxy-delta 12,14-prostaglandin J(2) delays lipopolysaccharide-induced preterm delivery and reduces mortality in the newborn mouse," Endocrinology, vol. 150, no. 2, pp. 699-706, 2009. 


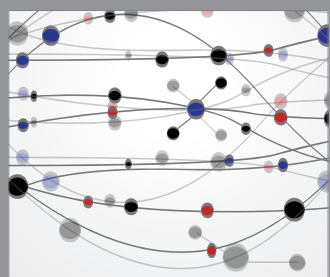

The Scientific World Journal
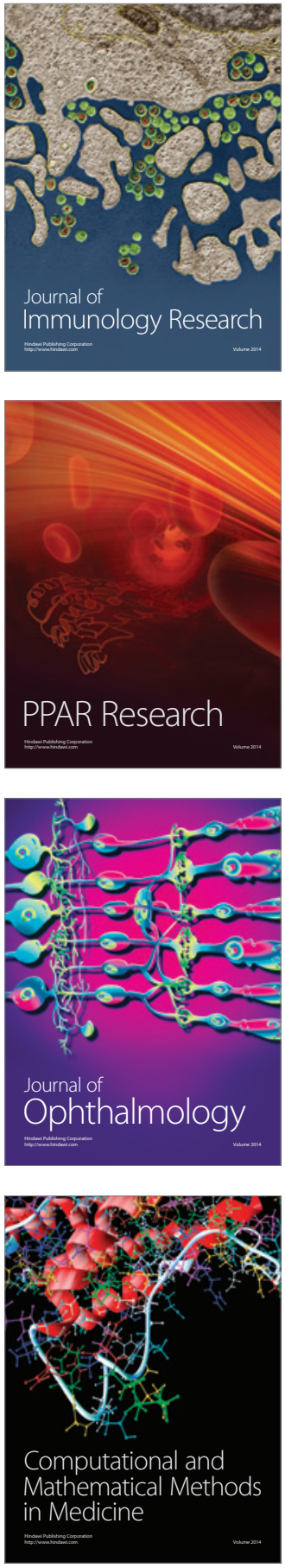

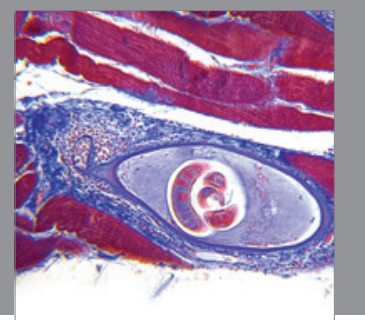

Gastroenterology

Research and Practice
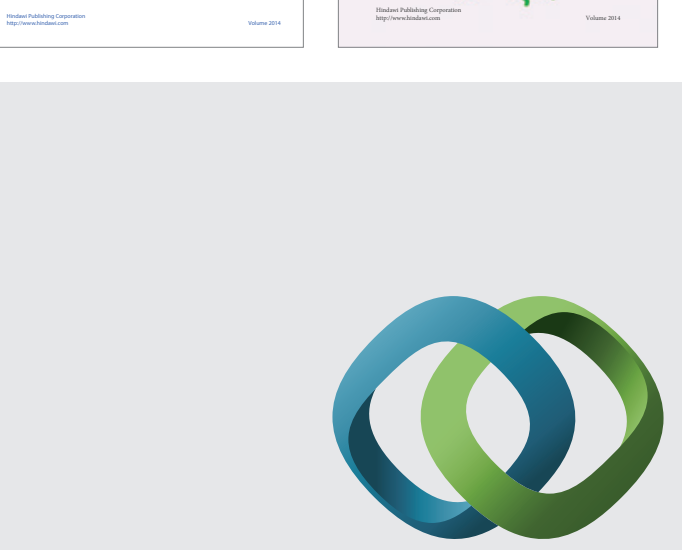

\section{Hindawi}

Submit your manuscripts at

http://www.hindawi.com
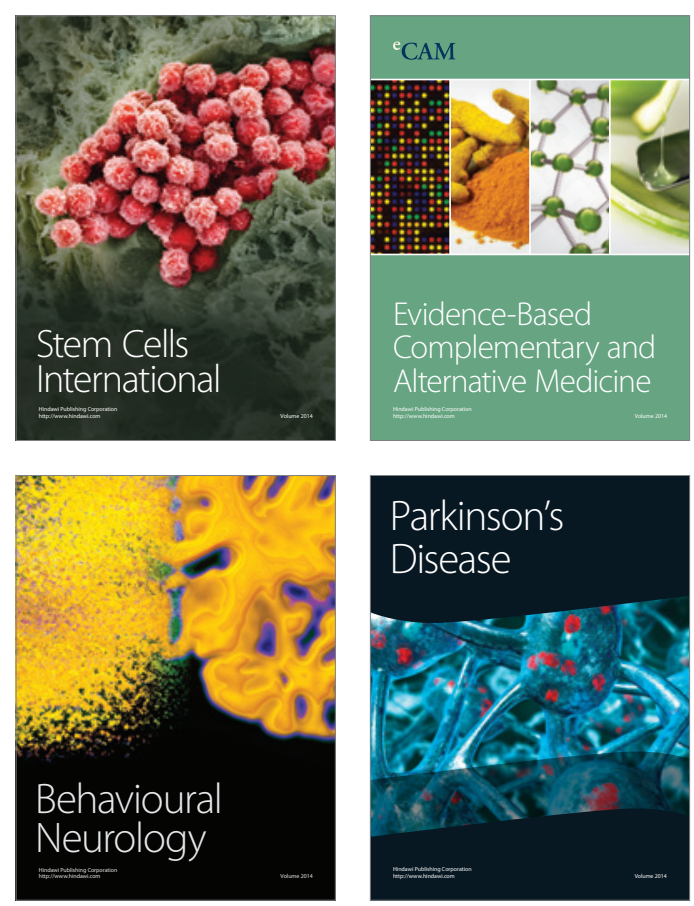

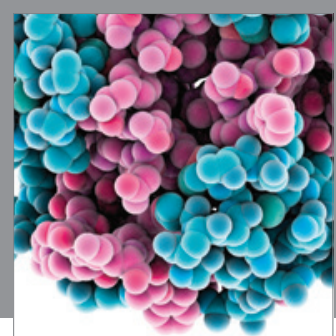

Journal of
Diabetes Research

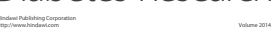

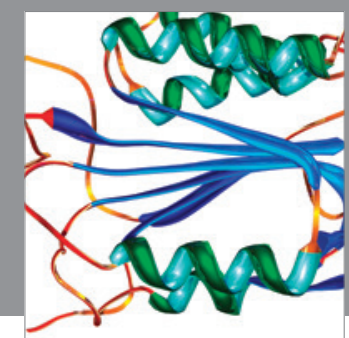

Disease Markers
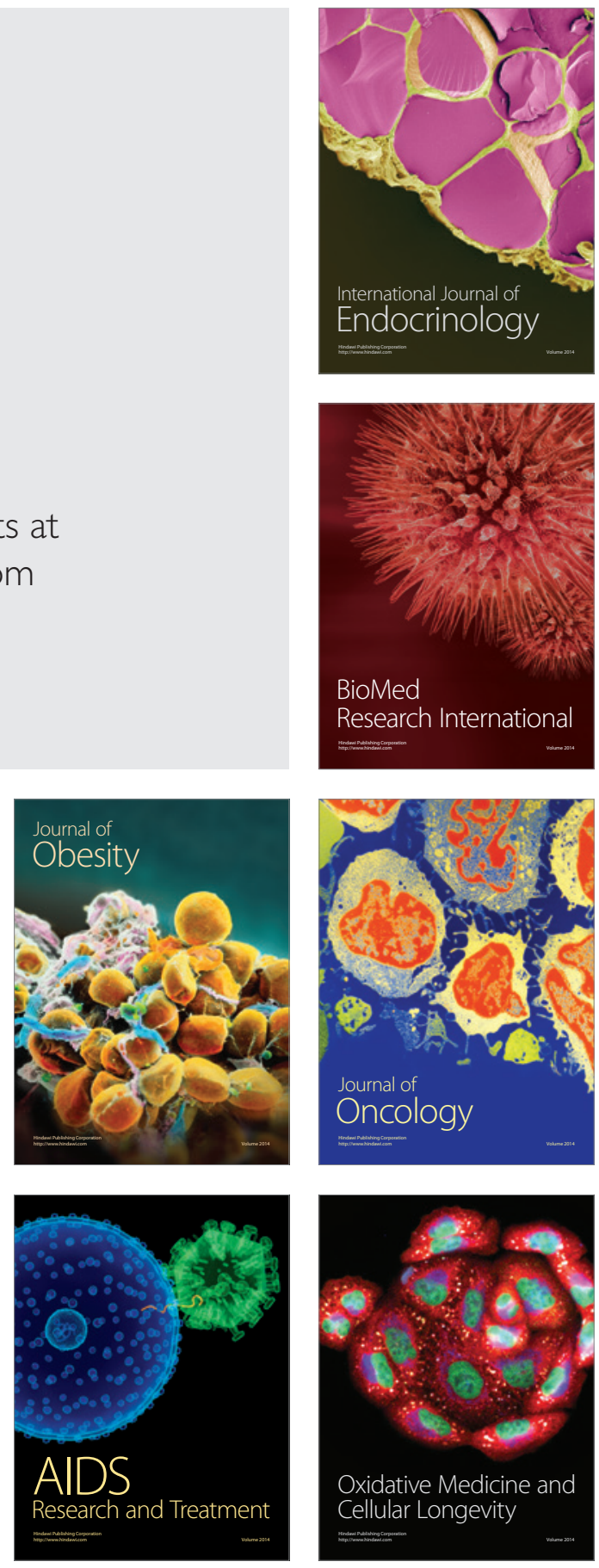